\title{
EFFECT OF DIFFERENT PLANT DENSITIES ON THE FRUIT YIELD AND SOME RELATED PARAMETERS AND STORAGE LOSSES OF FODDER WATERMELON (Citrillus lanatus var. citroides) FRUITS
}

\author{
Yasar Tuncer KAVUT ${ }^{*}$, Hakan GEREN ${ }^{I}$, Aleksandar SIMIĆ ${ }^{2}$ \\ ${ }^{I}$ Ege University, Faculty of Agriculture, Dept. of Field Crops, Izmir, TURKEY \\ ${ }^{2}$ University of Belgrade, Faculty of Agriculture, Zemun-Belgrade, SERBIA \\ *Corresponding author: tuncer.kavut@ege.edu.tr
}

Received: 20.06.2014

\begin{abstract}
This study was conducted in order to determine the effect of different plant densities $(4762,7143,9524,14286$, 28571 plants $\mathrm{ha}^{-1}$ ) on the fruit yield and some other yield components of fodder watermelon under typical Mediterranean climate conditions during summer period of 2012 and 2013 . Results indicated that average number of fruit per plant increased by decreasing plant densities but not single fruit weight and soluble solid content. It was suggested that 9524 plants $\mathrm{ha}^{-1}(210 \times 50 \mathrm{~cm})$ of fodder watermelon was the most successful crop density regarding the total fruit yield $\left(189 \mathrm{t} \mathrm{ha}^{-1}\right)$. It was also concluded that fodder watermelon fruits can be easily stored 210 days with $24 \%$ weight loss without any rot.
\end{abstract}

Key words: fodder watermelon, plant density, fruit yield, brix, storage.

\section{INTRODUCTION}

Fodder watermelon (FWM) (Citrillus lanatus (Thunb.) Matsum. \& Nakai var. citroides (Balley) Mansf.) is a new species for agricultural potential in Turkey or some European countries like Serbia, Bosnia \& Herzegovina and resembling ecologies (Acar, 2009). The fodder watermelon is a cucurbitaceous originating from Africa, introduced in the Northeast by the slaves, that through hybridization with other species of the genus is being diffused until today (Silva, 2003).

FWM is possibly a promising crop for growing in Turkey and other countries because of the following: i) a good stogare quality of the fruit; its fruit can be stored for one year, due to a high content of pectins; ii) large fruit and high yields; the fruit reach a weight of 15 to $20 \mathrm{~kg}$; iii) resistant to a number of diseases and lesser demands on cultivation conditions (Simić et al., 2013). However, together with these mentioned qualities, there are also certain shortcomings: fairly late ripening and a fruit pulp which is not sweet and is too compact (Simić et al., 2011). The fruits of FWM used as a flavourant especially for straw in winter-feeding of animals and their hulled kernels are also a high protein $(18.1 \%)$ and oil $(23.3 \%)$ source (Acar et al., 2012).

Some farmers in northeast Brazil feed their animals by FWM during the dry season as they have jumbo fruit (sometimes more than $15 \mathrm{~kg}$ ) (Aquino et al., 2000). Depending on the amount and distribution of the rainfall in Brazil, one hectare of the brushwood area can produce between 25 and 30 tons of the fruits. Storage of the production in the actual field is cheap and practical, allowing for conservation of the fruits during the dry season. The fodder species, on the contrary of traditional watermelons, has a skin tough enough to resist impact and deterioration, white and generally consistent pulp with a low sugar content, which renders it tasteless (Simić et al., 2013). Silva et al. (2009) recommended the fodder watermelon meal with hay for lambs in the ratio 35 to $66 \%$ of ration.

Some experiments on FWM indicated that the fruit yield depend on sowing date and plant density (Geren et al., 2011; Simić et al., 2011). As is the other cultivated plant, optimum plant density is an important factor in maximizing yields of FWM. Thus, the optimum plant density or plant population for any given situation results in mature plants that are sufficiently crowded to efficiently use resources such as water, nutrients, and sunlight, yet not so crowded that some plants die or are unproductive (Lyon, 2009). At this population, production from the entire field is optimized, although any individual plant might produce less than would have occurred with unlimited space.

Many factors influence the optimum plant population for a crop: availability of water, nutrients and sunlight; length of growing season; potential plant size; and the plant's capacity to change its form in response to varying environmental conditions (Ramírez et al, 2009). Currently, a common commercial (edible) triploid watermelon 
spacing is $244 \mathrm{~cm}$ by $92 \mathrm{~cm}$ or approximately $2.3 \mathrm{~m}^{-2}$ per plant (Schultheis et al., 2009). Acar et al. (2014) reported that number of fruit per plant and total fruit yield of FWM at density of 8334 plant ha $^{-1}(1.5 \mathrm{~m} \mathrm{x} 0.8 \mathrm{~m})$ were 1.41 and $66 \mathrm{t} \mathrm{ha}^{-1}$, respectively.

Generally, higher plant populations are suggested for lighter, less productive soils than for heavier, more productive soils. Watermelons can compensate somewhat for differences in plant population through adjustments in fruit size. Akimtoye et al. (2009) reported that average fruit weight of commercial watermelon decreased with increased planting density.

Walters (2009) investigated different crop densities (6150, 7687, 10252, 15377, 20502, 30754 plant $\left.\mathrm{ha}^{-1}\right)$ on mini watermelon cultivars and reported that although number of fruit per plant decreased with increased plant density, the total fruit yield increased by increasing of plant population. Optimisation of plant density is necessary in FWM production.

The objective of this research was to evaluate the influence of different planting densities on the fruit yield, some yield components and storage losses of FWM under irrigated conditions of Mediterranean climate.

\section{MATERIALS AND METHODS}

\section{Location of Experiment}

Field experiment was conducted during the main cropping seasons in 2012 and 2013 on a private farm in Soke-Aydin, located about $35 \mathrm{~m}$ above sea level. The climate is typical Mediterranean, with temperate and rainy winter season, and hot and dry summer. Average temperature of experimental area was $26.5-23.8^{\circ} \mathrm{C}$, total precipitation 13-44 $\mathrm{mm}$ and relative humidity $51-56 \%$ from beginning of June to end of October in 2012 and 2013 , respectively. The soil had loamy texture $(65 \%$ silt, $20 \%$ clay and $15 \%$ sand) with a $\mathrm{pH}$ of $7.1,3.3 \%$ organic matter, $1.2 \% \mathrm{CaCO}_{3}, 31.0$ ppm available $\mathrm{P}$ and $218.0 \mathrm{ppm}$ available K. There was not any limiting factor in terms of meteorological conditions and soil properties to grow FWM. The preceding crop at experimental site was Vicia villosa.

\section{Field applications and experimental design}

A local FWM population originated from Turkmenistan was used as plant material. The field experiment was set up in a randomised complete block design with three replications. Six plant densities (70x50, $70 \times 100,140 \times 50,140 \times 100,210 \times 50,210 \times 100 \mathrm{~cm}$ or 28571, 14286, 14286, 7143, 9524, 4762 plants ha $^{-1}$, respectively) were evaluated. The experimental plots were sown in five rows (for $70 \mathrm{~cm}$ apart), three rows (for 140 $\mathrm{cm}$ apart) and two rows (for $210 \mathrm{~cm}$ apart) (width of plot was $3.5 \mathrm{~m}) 7 \mathrm{~m}$ long on 10 June 2012 and 2013 by hand. Four FWM seeds with high germination rate (98\%) sown directly into soil at 2-3 cm depth. Seedlings with 3-5 leaf stage were singled out per hole. Crops were fertilised by $800 \mathrm{~kg} \mathrm{ha}^{-1}$ NPK $(15: 15: 15)$ and $200 \mathrm{~kg} \mathrm{ha}^{-1}$ ammonium nitrate $(33 \%)$. In both years, the plots in the field were irrigated by drip irrigation method in every 8 days until the end of harvest season. The weed was controlled twice by hand-hoed.

\section{Measurements}

Harvest was performed only once at the end of growing seasons on 29 October 2012 and 2013. All fruits were collected from the plots and the following measurements were recorded: number of fruits per plant, fruit yield $\left(\mathrm{kg} \mathrm{ha}^{-1}\right)$, average fruit weight $\left(\mathrm{kg} \mathrm{fruit}^{-1}\right)$ and total soluble solids concentration (brix). The soluble solid content of the juice obtained from the central endocarp was determined by a refractometer. The samples were randomly selected by taking 3 fruits of different sizes (marked with numbers) from each plant density treatment and stored during 7 months in an ordinary dark warehouse (uncontrolled) condition. They weighted monthly, and the mean of the loss percentage of each marked samples was calculated on the basis of the weight of the fresh samples in both years.

\section{Statistical analysis}

All data were statistically analyzed using analysis of variance (ANOVA) with the Statistical Analysis System (SAS, 1998). Probabilities equal to or less than 0.05 were considered significant. If ANOVA indicated differences between treatment means a LSD test was performed to separate them.

\section{RESULTS AND DISCUSSION}

The results indicated that the effects of different plant population densities of FWM were statistically significant but not year except on soluble solid content of the juice.

\section{Number of fruit}

There were statistically significant differences among plant densities regarding average number of fruit per plant (Table 1). Minimum plant density being 4762 crop ha $^{-1}$ had the highest average number of fruit (5.32 fruit plant $\left.{ }^{-1}\right)$, whereas maximum plant density being 28571 crop ha $^{-1}$ was the lowest (1.80 fruit plant $\left.{ }^{-1}\right)$. It was found that lower plant population of fodder watermelon increased average number of fruit per plant in the experimental area.

There are many reports and reviews on the theoretical aspects of the relationship between number of fruit and plant population density (NeSmith, 1993; Akimtoye et al. 2009; Walters, 2009). In general, increasing a plant population produces a greater yield per unit land area for most crops up to some upper limit or threshold density for the species, after which further increases in plant density either maintain the same yield or cause yield decline (Sanders et al., 1999). NeSmith (1993) reported that marketable fruit number increased 3.75 to 5.75 plant $^{-1}$ as plant population increased from 3030 plant ha $\mathrm{ha}^{-1}(1.5-2.2$ $\mathrm{m})$ to 7407 plant $\mathrm{ha}^{-1}(1.5-0.9 \mathrm{~m})$ in commercial watermelon. Some researchers emphasized that average number of fruits of FWM were 5.7, 2.5 or 1.4 per plant under the ecological conditions of Belgrade (Simić et al., 2013), Izmir (Geren et al., 2011) and Konya (Acar et al., 2014), respectively. 
Table 1. Effect of different plant populations on the fruit yield and other yield components of FWM grown under Soke ecological conditions in different years.

\begin{tabular}{|c|c|c|c|c|c|c|}
\hline \multirow{2}{*}{$\begin{array}{l}\text { Plant Density } \\
\left.\text { (plant ha' }{ }^{-1}\right)\end{array}$} & 2012 & 2013 & Mean & 2012 & 2013 & Mean \\
\hline & \multicolumn{3}{|c|}{ Average number of fruit per plant } & \multicolumn{3}{|c|}{ Average fruit weight (kg) } \\
\hline $28571(70 \times 50 \mathrm{~cm})$ & 1.81 & 1.78 & $1.80 \mathrm{~d}$ & 2.14 & 1.98 & $2.06 \mathrm{~d}$ \\
\hline $14286(70 \times 100 \mathrm{~cm})$ & 2.22 & 2.33 & $2.27 \mathrm{c}$ & 4.16 & 4.35 & $4.26 \mathrm{c}$ \\
\hline $14286(140 \times 50 \mathrm{~cm})$ & 2.19 & 2.25 & $2.22 \mathrm{~cd}$ & 4.31 & 4.32 & $4.32 \mathrm{c}$ \\
\hline $7143(140 \times 100 \mathrm{~cm})$ & 4.12 & 4.29 & $4.21 \mathrm{~b}$ & 4.83 & 4.64 & $4.74 \mathrm{~b}$ \\
\hline $9524(210 \times 50 \mathrm{~cm})$ & 4.59 & 4.62 & $4.61 \mathrm{~b}$ & 4.86 & 4.96 & $4.91 \mathrm{~b}$ \\
\hline \multirow{3}{*}{$\begin{array}{r}4762(210 \times 100 \mathrm{~cm}) \\
\text { Mean } \\
\operatorname{LSD}(0.05)\end{array}$} & 5.31 & 5.32 & $5.32 \mathrm{a}$ & 5.18 & 5.25 & $5.22 \mathrm{a}$ \\
\hline & 3.37 & 3.43 & 3.40 & 4.25 & 4.24 & 4.25 \\
\hline & \multicolumn{3}{|c|}{ Total fruit yield $\left(\mathrm{t} \mathrm{ha}^{-1}\right)$} & \multicolumn{3}{|c|}{ Soluble solid content $(\%)$} \\
\hline $28571(70 \times 50 \mathrm{~cm})$ & 88.67 & 90.91 & $89.79 \mathrm{e}$ & 1.88 & 1.89 & $1.88 \mathrm{~d}$ \\
\hline $14286(70 \times 100 \mathrm{~cm})$ & 109.93 & 112.11 & $111.02 \mathrm{~d}$ & 1.97 & 2.07 & $2.02 \mathrm{c}$ \\
\hline $14286(140 \times 50 \mathrm{~cm})$ & 110.10 & 111.62 & $110.86 \mathrm{~d}$ & 2.01 & 2.08 & $2.05 \mathrm{c}$ \\
\hline $7143(140 \times 100 \mathrm{~cm})$ & 120.14 & 118.54 & $119.34 \mathrm{c}$ & 1.98 & 2.18 & $2.08 \mathrm{c}$ \\
\hline $9524(210 \times 50 \mathrm{~cm})$ & 190.45 & 188.19 & $189.32 \mathrm{a}$ & 2.42 & 2.46 & $2.44 \mathrm{~b}$ \\
\hline $4762(210 \times 100 \mathrm{~cm})$ & 133.65 & 137.42 & $135.53 \mathrm{~b}$ & 3.37 & 3.55 & $3.46 \mathrm{a}$ \\
\hline Mean & 125.49 & 126.46 & 125.98 & 2.27 & 2.37 & 2.32 \\
\hline LSD (0.05) & Y:ns P:5.61 & YxP:ns C & .72 & Y:0.08 P:0.13 & YxP:ns & 4.77 \\
\hline
\end{tabular}

Y: year, P: plant population, YxP: interaction, ns: not significant, $\mathrm{CV}$ : coefficient of variation

Means in the same columns followed by the same letters are not significantly different at the 0.05 level.

\section{Fruit weight}

The effect of plant population on average fruit weight of FWM was significant (Table 1). The highest average fruit weight was recorded at $210 \times 100 \mathrm{~cm}\left(4762\right.$ plant ha $\left.^{-1}\right)$ $(5.22 \mathrm{~kg})$ as compared to $70 \times 50 \mathrm{~cm}(28571$ plant ha-1) $(2.06 \mathrm{~kg})$. It is possible that the lower number of plants per unit area helps the growth of plants because of better accessibility of light, fertilizer nutrients and water, thereby increasing the accumulation of nutritive ingredients in the fruits. These results are in agreement with those recorded by Schultheis et al. (2009). Sanders et al. (1999) investigated different crop densities (4444 [1.5-0.45m], 5555 [1.5-0.60m], 7407 [1.5-0.90m], 11111 [1.5-1.2m], $14815[1.5-1.5 \mathrm{~m}]$ plant $\mathrm{ha}^{-1}$ ) on commercial watermelon cultivars and reported that although number of fruit per plant decreased with increased plant density, fruit weight per plant $(7.5$ to $10 \mathrm{~kg})$ slightly increased by increasing of plant population. They also stated that higher population caused higher cull fruits number. Generally, higher plant populations are suggested for lighter, less productive soils than for heavier, more productive soils. Watermelons can compensate somewhat for differences in plant population through adjustments in fruit size, and, appear to be able to exploit the below- and aboveground resources (water, nutrients, light) equally well whether or not they are uniformly spaced (Lyon, 2009).

\section{Total fruit yield}

Significant difference in total fruit yield was recorded among plant populations. The highest fruit yield $(189.32 \mathrm{t}$ $\mathrm{ha}^{-1}$ ) was obtained at $210 \times 50 \mathrm{~cm}\left(9524\right.$ plant $\left.^{-1}\right)$ while the least value $\left(89.79 \mathrm{t} \mathrm{ha}^{-1}\right)$ was obtained with $70 \times 50 \mathrm{~cm}$ (28571 plant $\mathrm{ha}^{-1}$ ). Fruit yield of FWM gradually increased with the decreasing plant density until 9524 plant $\mathrm{ha}^{-1}$, but following that density, yield was also decreased due to the lack of the number of plants per unit area. Though lower densities increased yield per hectare, it leads to an increase in the fruit mass $\left(\mathrm{kg}\right.$ fruit $\left.^{-1}\right)$ which may be attributed to limited competition among plants for sunlight and nutrients. Sanders et al. (1999) and Walters (2009) reported that the total fruit yield increased by increasing of plant population.

Duthie et al. (1999) indicated that watermelon yield per plant tends to decrease with higher plant densities because interspesific competition intensifies and this directly suppresses plant growth, resulting in lower yields per plant. Although Duthie et al. (1999) suggested that high plant populations (18150 and 12100 plants $\mathrm{ha}^{-1}$ ) provided the greatest marketable numbers of fruit, our results indicated that lower plant density (9524 plants ha) can be used to increase FWM number and weight. However, there is a paucity of information concerning the influence of plant population on FWM yield and yield components, particularly available information to growers. Some researchers reported that total fruit yield of FWM were 152,88 or $66 \mathrm{t} \mathrm{ha}^{-1}$ at different plant densities under the ecological conditions of Belgrade (Simić et al., 2013), Izmir (Geren et al., 2011) and Konya (Acar et al., 2014), respectively.

\section{Soluble solid content (SSC)}

There were significant differences among plant densities in terms of SSC. Minimum plant density (4762 plant $\left.\mathrm{ha}^{-1}\right)$ had the highest $\operatorname{SSC}(3.46 \%)$, whereas maximum plant density (28571 plant ha ${ }^{-1}$ ) was the lowest SSC $(1.88 \%)$. Year effect was also significant and average SSC of first year (\%2.27) was lower than the second year (\%2.37). No interaction was detected between year and plant density. It was found that lower plant population increased the soluble solid content of FWM juice in 
experimental area. As expected, the soluble solid contents of FWM were lower compared to commercial (edible) triploid watermelon genotypes (Akimtoye et al., 2009; Walters, 2009). Walters (2009) and Schultheis et al. (2009) reported that watermelon fruit quality was not influenced by plant density, but was frequently affected by cultivar.

\section{Storage losses}

Effect of year, storage period, plant population and the interaction among them on storage losses (fresh weight) were significant. The highest weight loss was recorded in $70 \times 50 \mathrm{~cm}$ spacing and storing period of 210 days in 2013 being \%28.9 as compared to minimum loss in $210 \times 100$ $\mathrm{cm}$ and storing period of 30 days in 2013 being $\% 2.4$ (Table 2). In our study, generally, prolonged storage period and increasing plant populations increased weight loss in fruits of FWM. Lower plant population in FWM reduced weight loss due to higher SSC values and thickness of the rind. For example, the loss after 210 days in population of 9524 plant $^{-1} \mathrm{a}^{-1}$ ranged between 22.2 and $21.9 \%$ for warehouse storage in 2012 and 2013, respectively. These results are comparable to those reported by Simić et al. (2012) in which they reported that the weight loss was below $10 \%$ (in Belgrade) or below $20 \%$ (in Izmir) after 7 months at uncontrolled storage conditions. Also some researchers (Geren et al. 2011; Acar et al., 2012) reported that the weight loss in FWM varies according to the size and shape of the exposed surface. The big fruits relatively loose more weight than smaller ones.

Table 2. Effects of different storage period and plant population on the loss (\%) of fresh weight of FWM grown under Soke ecological conditions in different years

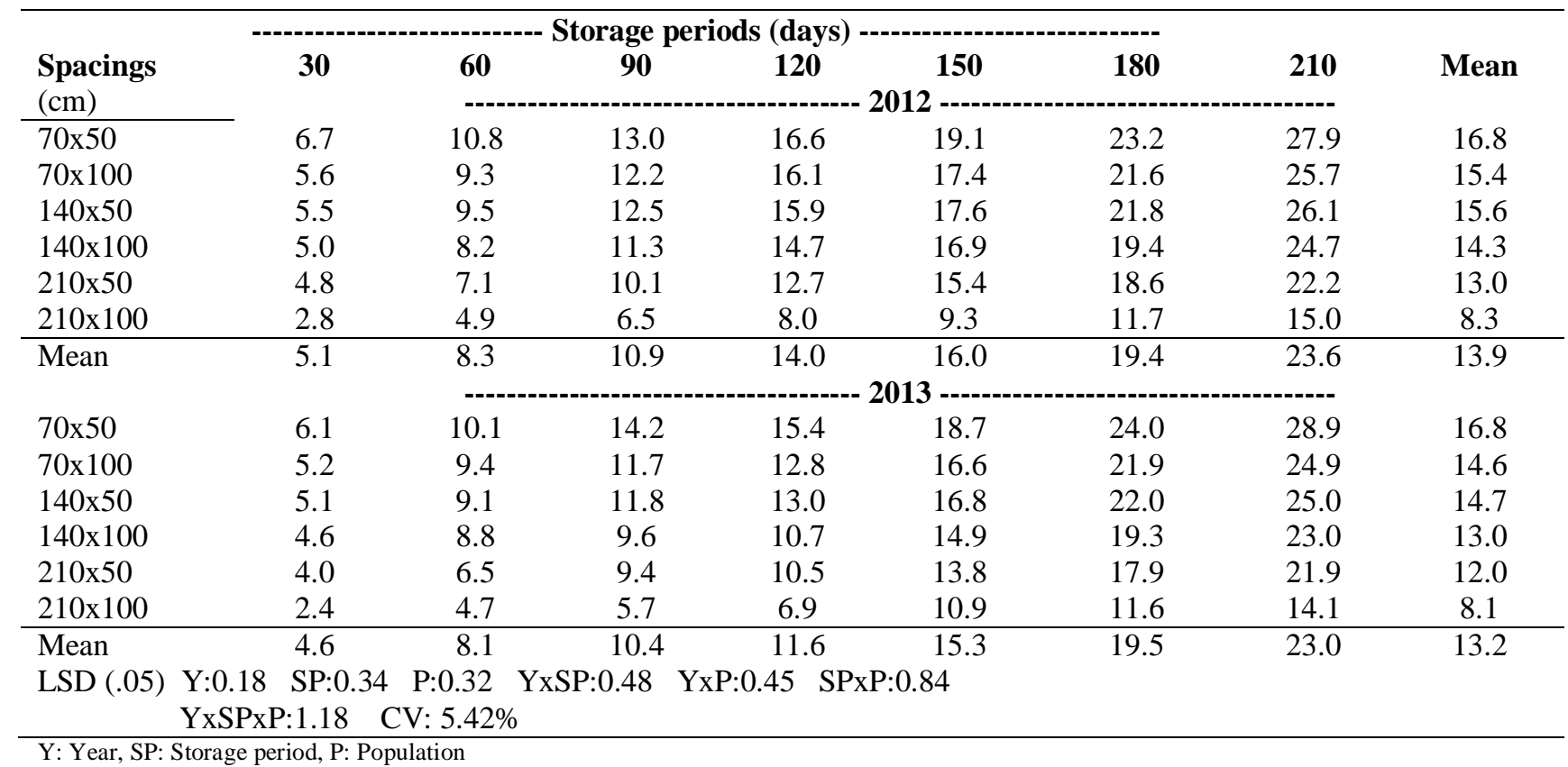

Y: Year, SP: Storage period, P: Population

Storage of the FWM production is cheap and practical, allowing for conservation of the fruits during the long period with low losses of fresh weight. Storage losses caused by respiration have been controlled through the utilization of forced-air ventilation (Acar, 2009). He also suggested that to cover the clump with $20 \mathrm{~cm}$ of straw or a suitable cover material for protecting FWM fruits from low temperatures and frost. Ventilation is required to reduce heat build up and rotting. It was also concluded that FWM fruits can be easily stored 210 days with $24 \%$ weight loss without any rot.

\section{CONCLUSION}

This study was performed to determine the effect of different planting densities on fruit yield and some yield components and storage losses of FWM under irrigated conditions of Mediterranean climate.
Higher plant densities of FWM produced significantly lower yield per hectare compared to lower densities. These results can be attributed to lower competition among plants for the availability of nutrients, sunlight and space. Our results indicate that plant densities influenced the weight, number and mass ( $\mathrm{kg}^{\text {fruit }}{ }^{-1}$ ) of FWM fruits. It was suggested that 9524 plants $\mathrm{ha}^{-1}(210 \times 50 \mathrm{~cm})$ of FWM was the most productive crop population regarding the total fruit yield $\left(189.32 \mathrm{t} \mathrm{ha}^{-1}\right)$ compared to higher plant densities (14286 or 28571 plants ha ${ }^{-1}$ ). The mature FWM fruits can be conserved for more than half a year without significant losing their nutritional qualities and without any rot. It is important that their conservations are viable without the need for sophisticated storage practices. Future experiments on FWM should be conducted at different locations with various agronomical treatments and additional plant densities to be sure that results are relatively consistent over time. 


\section{ACKNOWLEDGEMENTS}

We express our gratitude to Asc. Prof. Dr. Ramazan ACAR, Selcuk University Faculty of Agriculture Dept. of Field Crops, Konya/Turkey for providing the seeds of FWM. We also thank to Prof. Dr. Riza AVCIOGLU Ege University Faculty of Agriculture Dept. of Field Crops, Izmir/Turkey for his kind and valuable critical review of the manuscript.

\section{LITERATURE CITED}

Acar, R. 2009. Forage watermelon (Citrillus lanatus (Thunb.) Matsum. \& Nakai var. citroides (Balley) Mansf.), Republic of Turkey, Ministry of Agriculture and Rural Affairs, Vol:3, pp:784-788.

Acar, B., R. Acar, B. Uzan and M. Direk. 2014. Effect of different irrigation levels on forage watermelon yield in Middle Anatolian Region of Turkey, International Journal of Agriculture and Economic Development, 2(1):10-15.

Acar, R., M.M. Özcan, G. Kanbur and N. Dursun. 2012. Some physico-chemical properties of edible and forage watermelon seeds, Iran. J. Chem. Eng., 31(4):41-47.

Akimtoye, H.A., A.A. Kintomo and A.A. Adekunke. 2009. Yield and fruit quality of watermelon in response to plant population, International J.of Veg. Sci, 15:369-380.

Aquino, J.G., M.A. Queiroz, S.M.C. Araujo, G. Bandel and P.S. Martins. 2000. Implications of the introgression between Citrillus colocynthis and C.lanatus characters in the taxonomy, Evoluationary dynamics and breeding of watermelon. Plant Gen.Resour.Newsl, 121, 15-19.

Duthie, J.A., J.W. Schrefler, B.W. Roberts and J.V. Edelson. 1999. Plant density dependent variation in marketable yield, fruit biomass, and marketable fraction in watermelon. Crop Sci. 39:406-412.

Geren, H., R. Avcioglu, H. Soya, B. Kir, G. Demiroglu and Y.T. Kavut. 2011. A preliminary investigation on the yield and some yield characteristics of forage watermelon (Citrillus lanatus (Thunb.) Matsum. \& Nakai var. citroides (Balley) Mansf.) grown as second crop, 4th National Seed Congress of Turkey, 14-17 June 2011, Samsun, Vol.2, p.157-161.

Lyon, D.J. 2009. How do plant populations affect yield? Agricultural Research Division of IANR, University of Nebraska - Lincoln.

NeSmith, D.S. 1993. Plant spacing influences watermelon yield and yield components, Hort.Science, 28(9):885-887.
Ramírez, M.V.H., M.R. Salinas and F.C. Ferre. 2009. Influence of grafted watermelon plant density on yield and quality in soil infested with melon necrotic spot virus, Hort.science 44(7):1838-1841.

SAS Institute. 1998. INC SAS/STAT user's guide release 7.0, Cary, NC, USA.

Sanders, D.C., J.D. Cure and J.R. Schultheis. 1999. Yield response of watermelon to planting density, planting pattern, and polyethylene mulch, Hort.science, 34(7):1221-1223.

Schultheis, J., R. Hassell, T. Kelley, R. Kumar, G. Miller, S. Olson and T.C. Wehner. 2009. Grafted watermelon: evaluation of rootstocks, cultivars and planting density for high yield and Fusarium wilt control, North Carolina State University, www.nationalwater melonassociation.com

Silva, R.L.N.V. 2003. Chemical composition, intake and apparent digestibility of diets containing different levels of forage watermelon bran (Citrullus lanatus cv. citroides) and guandu hay (Cajanus cajan cv. D1 Type), in sheep. Salvador, Bahia, 2003 82f. Dissertation (Master's degree in Tropical Veterinary Medicine), School of Veterinary Medicine, Federal University of Bahia.

Silva, R.L.N.V., G.G.Leal de Araújo, E.P.do Socorro, R.L.Oliveira, A.F.G.Neto and A.R.Bagaldo. 2009. Levels of forage watermelon meal in diets for sheep. Revista Brasileira de Zootecnia 38(6):1142-1148.

Simić, A., H. Geren, S. Vučković, S. Petrović and Ž. Dželetović. 2012. Comparison of fruit yield and some yield characteristics of forage watermelon (Citrullus lanatus var. citroides) grown in Turkey and Serbia, Proceedings of the First International Symposium on Animal Science, November 8th-10th, 2012, Book I, pp.496-503.

Simić, A., S. Vučković, S. Petrović, H. Geren and Đ. Moravčević. 2011. Possibilities of growing forage watermelons in Serbia. 5th Symposium with international Participation "Innovations in Crop and Vegetable Production", Belgrade 20-22 October, Serbia, Book of abstracts, p.85-86.

Simić, A., H. Geren, S. Vučković, S. Petrović and Đ. Moravčević. 2013. Fruit yield and quality of irrigated forage watermelon (Citrullus lanatus var. citroides) grown in Serbia. 2nd International Symposium and 18th Scientific Conference of Agronomists of Republic of Srpska, Book of abstracts, Trebinje, Bosnia and Herzegovina, March 26-29, 2013, p:178-179.

Walters, S.A. 2009. Influence of plant density and cultivar on mini triploid watermelon yield and fruit quality, Hort. Technology, 19(3):553-557. 